\title{
ASUHAN KEPERAWATAN DENGAN MASALAH UTAMA DEMAM TYPHOID
}

\author{
Amalina 'Izazi \\ Poltekkes Kemenkes Semarang, Prodi DIII Keperawatan Magelang \\ Email : izaziamalina@gmail.com
}

DOI : 10.24252/kesehatan.v11i2.6137

\begin{abstract}
Abstrak
Demam typhoid adalah penyakit yang disebabkan oleh infeksi bakteri Salmonella typhi. Penyakit ini masih menjadi masalah kesehatan terutama di negara berkembang. Penyakit ini berhubungan erat dengan personal hygiene dan lingkungan di sekitarnya seperti penggunaan air bersih, pengelolaan dan pembuangan sampah. Penularan demam typhoid bisa melalui fecal dan oral yang masuk ke dalam tubuh manusia melalui makanan dan minuman yang terkontaminasi. Tujuan umum dari jurnal ini adalah menggambarkan tentang pengelolaan asuhan keperawatan dengan masalah utama demam typhoid. Study Kasus ini menggunakan metode deskriptif yaitu menggambarkan tentang proses asuhan keperawatan dengan memfokuskan pada salah satu masalah penting dalam kasus yang dipilih yaitu asuhan keperawatan dengan masalah utama demam typhoid.
\end{abstract}

Kata kunci : Demam Typhoid, Penyebab, Kebersihan diri dan Kebiasaan Jajan.

\begin{abstract}
Typhoid fever is a disease caused by infection with Salmonella typhi bacteria. This disease is still a health problem, especially in developing countries. This disease is closely related to personal hygiene and the surrounding environment such as the use of clean water, management and garbage disposal. Transmission of typhoid fever can be through fecal and oral which enter the human body through contaminated food and drinks. The general purpose of this journal is to describe the management of nursing care with the main problem of typhoid fever. This case study uses descriptive method which describes the process of nursing care by focusing on one of the important problems in the chosen case, namely nursing care with the main problem of typhoid fever.
\end{abstract}

Keywords: Typhoid Fever, Causes, Personal Hygiene and Snacks

\section{PENDAHULUAN}

Manusia berkaitan erat dengan lingkungan sekitarnya, lingkungan yang sehat akan memberikan dampak positif dan timbal balik untuk manusia dan sebaliknya jika lingkungan dan gaya hidup tidak sehat, maka manusia akan mengalami dampak dari lingkungan dan gaya hidup tidak sehat tersebut seperti penyakit infeksi dan penyakit berbasis lingkungan misalnya adalah penyakit typhoid. Penyakit ini merupakan 
problem atau masalah yang serius bagi kesehatan masyarakat di negara- negara berkembang dan daerah dengan iklim tropis, seperti halnya Indonesia, penyakit typhus abdominalis dapat ditemukan sepanjang tahun (endemik)(Binongko, 2012).

Seperti yang dijelaskan oleh Widoyono (2011) Demam tyfoid adalah penyakit infeksi akut usus halus yang disebabkan oleh bakteri Salmonella typhi atau Salmonella paratyphi A, B dan C. penularan demam tyfoid melalui fecal dan oral yang masuk ke dalam tubuh manusia melalui makanan dan minuman yang terkontaminasi.

Berdasarkan data yang diperoleh, di seluruh dunia terdapat sekitar 17 juta kasus dengan 600.000 kematian per tahun akibat typhoid abdominalis. Dapat diperkirakan $70 \%$ kematian akibat typhoid abdominalis terjadi di Asia. Jika tidak segera diobati, 10 $20 \%$ penderita tersebut dapat berakibat fatal. Sekitar $2 \%$ dari penderita menjadi carrier/pembawa (Widoyono, 2011). Berdasarkan data dari Profil Kesehatan Indonesia tahun 2010 tifus abdominalis menempati urutan ke 3 dari 10 besar penyakit rawat inap di rumah sakit Indonesia dengan CFR 0,67\% (KEMENKES, 2012).

Pada orang yang kurang mampu bila sakit tidak berobat ke sarana kesehatan medis hal ini dikarenakan masalah biaya, sehingga bila mereka menjadi penjamah makanan maka mereka akan menjadi sumber penularan penyakit kepada masyarakat yang menjadi pembeli jajanan tersebut. Risiko penularan melalui penjual makanan di jalanan yang kebersihannya buruk memperbanyak jumlah kasus demam typhoid (Anonim, 2013).

Penyakit ini erat kaitannya dengan hygiene pribadi dan sanitasi lingkungan, seperti hygiene perorangan, hygiene makanan, lingkungan yang kumuh, kebersihan tempattempat umum yang kurang serta perilaku masyarakat yang tidak mendukung untuk hidup sehat. (Depkes RI, 2006)

Penularan tifus abdominalis secara langsung hanya sekitar 10\%. Makanan dan minuman yang menjadi sumber penularan adalah makanan dan minuman yang tidak dimasak dengan baik (kurang matang). Makanan yang sudah dimasak dengan baik juga dapat menularkan tifus abdominalis jika kontak dengan tangan yang kotor atau air yang mengandung bakteri salmonella thypi (Djauli, 2009).

Feses penderita merupakan sumber utama bagi penularan demam tyfoid (Widoyono, 2011). Secara umum, untuk memperkecil kemungkinan tercemar salmonella typhi, maka setiap individu diharapkan untuk memperhatikan kualitas makanan atau minuman yang akan dikonsumsi. Bakteri salmonella typhi akan mati dalam air yang dipanaskan dengan suhu tinggi yakni $57^{\circ} \mathrm{C}$ dalam beberapa menit atau dengan proses iodinasi atau klorinasi. Pencegahan demam tyfoid melalui gerakan nasional sangat diperlukan karena akan berdampak cukup besar terhadap penurunan angka kejadian demam typhoid (Soegijanto, 2002). 
Data World Health Organization (WHO) pada tahun 2009, memperkirakan terdapat 17 juta kasus demam typhoid di seluruh dunia dengan insidensi 600.000 kasus kematian tiap tahun Case Fatality Rate (CFR) $=3,5 \%$. Berdasarkan Laporan Ditjen Pelayanan Medis Departemen Kesehatan RI tahun 2008, demam typhoid menempati urutan ke 2 dari 10 penyakit terbanyak pasien rawat inap di Rumah Sakit di Indonesia dengan jumlah kasus 81.116 dengan proporsi 3,15\% (Depkes RI, 2009).

Kebersihan diri salah satu penularan dari penyakit saluran pencernaan adalah melalui tangan yang tercemar oleh mikroorganisme yang merupakan penyebab penyakit. Mencuci tangan sesudah buang air besar, mencuci tangan sebelum makan akan melindungi seseorang dari infeksi penyakit kemudian kondisi kuku jari tangan seseorang juga mempengaruhi terjadinya demam typhoid, mencuci tangan dengan benar menggunakan sabun serta air yang mengalir dapat menghilangkan mikroba yang menjadi sumber penyakit atau terkontaminasi dapat memindahkan bakteri dan virus pathogen dari tubuh, tinja atau sumber lain ke dalam makanan atau minuman. Kombinasi antara aktivitas sabun sebagai pembersih, penggosokan dan aliran air akan menghanyutkan partikel kotoran yang banyak mengandung mikroba (Rakhman, 2009). Berdasarkan uraian-uraian diatas, maka perlu dilakukan penelitian tentang asuhan keperawatan dengan masalah utama demam typhoid. Dengan rumusan masalah bagaimanakah asuhan keperawatan dengan masalah utama demam typhoid. Untuk mencapai tujuan menggambarkan pengelolaan asuhan keperawatan dengan masalah utama demam typhoid.

\section{METODOLOGI PENELITIAN}

Penelitian ini adalah penelitian dengan metode deskriptif yaitu menggambarkan tentang proses asuhan keperawatan dengan memfokuskan masalah demam typhoid pada tanggal 15, 16, 18 Januari 2018. Jumlah pasien 1 orang. Pengumpulan data dengan wawancara, observasi langsung, catatan medis. Analisa dan penyajian data disajikan secara narasi.

\section{HASIL DAN PEMBAHASAN}

Penelitian ini dilakukan pada tanggal 15, 16, 18 Januari 2018 dengan 1 pasien dengan demam typhoid. Usia pasien 16 tahun dengan jenis kelamin perempuan dan tingkat pendidikan SMA. Dari data yang didapatkan terdapat keluhan utama yaitu klien mengatakan nyeri dibagian perut, dari data obervasi keluarga dan pasien mengalami kecemasan dan ketidaktahuan terhadap penyakit yang diderita anaknya. Data lain yang ditemukan adalah pasien suka makan sembarangan, tidak memperhatikan kebersihan makanan dan asal makanan tersebut. Pasien selama di rumah jarang makan, hanya makan sedikit dalam sehari dengan data berat badan $50 \mathrm{~kg}$, tinggi badan $167 \mathrm{~cm}$, lingkar lengan 28,5 cm, lingkar kepala $56 \mathrm{~cm}$, dengan IMT (Indeks Massa Tubuh) 17,9 yaitu keadaan disebut kurus dengan kekuragan berat badan tingkat 
ringan atau KEK ringan. Dari data pemeriksaan fisik terdapat hasil tanda-tanda vital yang abnormal yaitu suhu $36,9^{\circ} \mathrm{C}$.

Dari data lain yang ditemukan adalah pemeriksaan penunjang terdapat pemeriksaan yang tidak normal yaitu jumlah lekosit 4.9 10^3/ul (normal : 3.6-11.0), jumlah eritrosit H5.69 10^6/ul (normal : 3.80-5.20), dan jumlah limfosit $\mathrm{H} 47.4 \%$ (normal: 25.0-40.0). Hasil neurologi S.Thyphi O yaitu (+)1/320, dan S.Thypi H (+) 1/80. Tindakan yang diberikan untuk pasien adalah diberikan asuhan keperawatan secara komprehensif dengan menggunakan strategi pelaksanaan. Setelah dilakukan asuhan keperawatan dengan strategi pelaksanaan terjadi penurunan nyeri dari skala 6 menjadi 3 , dan peningkatan pengetahuan keluarga dan pasien tentang pentingnya mencegah penyakit infeksi.

Pada saat pengkajian tanggal 15 Januari 2018 ditemukan data keluhan pasien yaitu klien nyeri perut dengan skala 6, pasien merasakan tidak nyaman seperti teremasremas dengan waktu terus menerus. Keluarga pasien mengatakan bahwa anaknya mengeluh sakit perut sudah lama sekitar 1 bulan yang lalu, keluarga klien mengira bahwa sakit perut yang dirasakan anaknya adalah sakit perut biasa. Tidak ada tindakan pengobatan untuk anaknya. Terdapat data bahwa pasien mengatakan kadang-kadang pingsan. Pada tanggal 15 Januari 2018 klien mengatakan sakit perut, mual dan muntah $2 \mathrm{X}$ disertai pusing. Keluarga pasien langsung membawa pasien ke Rumah Sakit di daerah Temanggung. Ditemukan data terkait dengan pola nutrisi metabolic yaitu keluarga pasien mengatakan bahwa pasien jarang makan dan selalu jajan sembarangan, tidak memperhatikan kebersihan dan asal usul makanan tersebut, data objektif menunjukkan mukosa bibir pasien kering.

Data tersebut sesuai dengan penelitian terdahulu yang telah dilakukan menunjukkan bahwa kejadian demam typhoid berkaitan dengan faktor sanitasi lingkungan dan hygiene perorangan. Pada penelitian Naelannajah Alladany (2010) mendapatkan hasil bahwa sanitasi lingkungan dan perilaku kesehatan yang merupakan faktor risiko kejadian demam typhoid adalah kualitas sumber air, kualitas jamban keluarga, pengelolaan sampah rumah tangga, praktek kebersihan diri, pengelolaan makanan dan minuman rumah tangga.

Terdapat data pemeriksan fisik yaitu keadaan umum cukup dan kesadaran composmentis, tanda-tanda vital : tekanan darah 120/80 $\mathrm{mmHg}$, Nadi $80 \mathrm{X} /$ menit, Pernafasan $18 \mathrm{X} /$ menit, dan Suhu $36,9^{\circ} \mathrm{C}$. Dari data tanda-tanda vital, pasien mengalami hipertermi. Tidak ada kelainan dalam pemeriksaan fisik bagian kepala, dada, genetalia. Data pemeriksaan ekstremitas pasien tidak terdapat edema, dan dapat bergerak bebas. Tangan kiri terpasang infus asering 20 tetes/menit. Berdasarkan data catatan medis terapi obat yang diberikan untuk pasien adalah infus asering 20 tetes/menit yaitu untuk mencegah dehidrasi. Injeksi ranitidine 2X1 ampul yaitu untuk mengurangi produksi asam lambung, injeksi ondancentron 3X1 ampul yaitu untuk mencegah mual 
serta meningatkan metabometabolime, injeksi ketorolac 3X1 ampul yaitu untuk mengurangi nyeri, injeksi ceftriaxone 2X1gram yaitu untuk mengatasi bakteri (antibiotic), dan drip paracetamol 3X500 gram yaitu untuk penurun panas/demam.

Hari pertama pengkajian tanggal 15 Januari 2018 didapatkan analisa data masalah keperawatan atau diagnosa keperawatan yaitu nyeri akut, hipertermi, ketidakseimbangan nutrisi kurang dari kebutuhan tubuh, dan definisi pengetahuan. Data yang pertama adalah dengan masalah keperawatan nyeri akut yaitu pasien mengatakan nyeri perut dengan skala 6, terasa seperti teremas-remas dan dalam waktu terus menerus, dari data objektif terlihat bahwa pasien tampak menahan nyeri, klien terus memegangi perut, hasil pemeriksaan penunjang didapatkan hasil neurologi S.Thyphi O yaitu $(+) 1 / 320$, dan S.Thypi $\mathrm{H}(+)$ 1/80.

Data kedua dengan masalah keperawatan hipertermi, pasien mengatakan bahwa pusing dan merasa demam dengan data objektif kulit terasa hangat, pasien terlihat gelisah, dan pemeriksaan suhu abnormal yaitu $36,9^{\circ} \mathrm{C}$. Data ketiga dengan masalah keperawatan ketidakseimbangan nutrisi kurang dari kebutuhan, pasien mengatakan bahwa hanya menghabiskan $1 / 2$ porsi rumah sakit dan hanya minum kurang lebih 6 gelas sehari, sedikit mual, data objektif menunjukkan bahwa berat badan $50 \mathrm{~kg}$, tinggi badan $167 \mathrm{~cm}$, dan mukosa bibir pasien kering. Data keempat dengan masalah keperawatan definisi pengetahuan, keluarga pasien mengatakan bahwa belum mengerti tentang penyakit yang dialami anaknya, data objektif terlihat bahwa keluarga pasien sering bertanya tentang penyakit anaknya.

Data rencana keperawatan didapatkan tujuan dan kriteria hasil serta intervensi. Terdapat empat masalah keperawatan yaitu nyeri akut, hipertermi, ketidakseimbangan nutrisi kurang dari kebutuhan tubuh, dan definisi pengetahuan yang dilakukan strategi pelaksanaan selama $3 \times 24$ jam. Masalah keperawatan pertama adalah nyeri akut dengan kriteria hasil Tidak ada ekspresi wajah nyeri, tidak ada nyeri yang dilaporkan, dan skala nyeri menjadi 3 dengan dilakukan intervensi dan implementasi, tentukan lokasi, karakteristik, dan keparahan nyeri (nyeri diperut dengan skala 6), observasi adanya petunjuk non verbal mengenai ketidaknyamanan verbal mengenai ketidaknyamanan (pasien mengatakan nyeri, dan pasien tampak memegangi perutnya), berikan informasi mengenai nyeri penyebab, ajarkan teknik relaksasi (nafas dalam). Masalah keperawatan yang kedua adalah hipertermi dengan kriteria hasil Suhu normal $\left(36^{\circ} \mathrm{C}\right)$, kulit tidak panas dengan intervensi pantau $\operatorname{TTV}\left(\right.$ suhu $\left.36,9^{\circ} \mathrm{C}\right)$, monitor asupan cairan, berikan dan ajarkan kompres hangat, Instruksikan pasien memakai baju tipis, kolaborasi pemberian obat (drip paracetamol 3x500gram). Masalah keperawatan yang ketiga adalah ketidakseimbangan nutrisi kurang dari kebutuhan tubuh dengan kriteria hasil asupan gizi baik/normal, asupan nutrisi, tidak ada mual dengan intervensi monitor TTV, monitor kalori asupan makanan dan cairan secara tepat(pasien hanya makan $1 / 2$ porsi), Anjurkan makan sedikit tapi sering, Ajarkan konsep nutrisi yang baik. Masalah keperawatan keempat adalah definisi pengetahuan dengan kriteria hasil pengetahuan 
banyak tentang penyakit, pengetahuan banyak tentang tanda, penanganan, pencegahan dengan intervensi kajian tingkat pengetahuan tentang penyakit, jelaskan proses penyakit, edukasi pasien dan keluarga tentang tanda, penanganan, dan pencegahan.

Pada tanggal 15 Januari 2018 masalah keperawatan nyeri akut, hipertermi, ketidakseimbangan nutrisi kurang dari kebutuhan tubuh, definisi pengetahuan didapatkan catatan perkembangan yaitu pasien mengatakan nyeri perut, mual, pusing, dan keluarga mengatakan tidak mengetahui penyakit yang dialami anaknya. Dengan data objektif nyeri berlokasi di perut, dengan skala 6, terasa seperti teremas-remas, hilang timbul. Pemeriksaan tanda-tanda vital dengan hasil Suhu $36,9^{\circ} \mathrm{C}$ dan akral hangat, pasien masih makan $1 / 2$ porsi makanan rumah sakit. Tindakan keperawatan selanjutnya adalah monitor TTV (tanda-tanda vital), monior nyeri, memberikan drip paracetamol 3x500gram, monitor kalori dan asupan makanan, dan berikan pendidikan kesehatan terkait dengan penyakit yang dialami pasien.

Catatan pekembangan tanggal 16 Januari 2018 didapatkan pasien mengatakan nyeri perut dengan skala 4 hilang timbul, sedikit mual, berdasarkan pemeriksaan suhu pasien turun menjadi $36,2^{\circ} \mathrm{C}$. Data objektif menunjukkan mukosa bibir kering, diet puasa karena pasien akan dilakukan USG pada perut. Intervensi selanjutnya adalah monitor suhu, monitor nyeri (memberikan injeksi ceftriaxone 1gram $(10 \mathrm{ml})$, ketorolac 1 ampul, dan monitor asupan makanan.

Catatan perkembangan tanggal 18 Januari 2018 didapatkan pasien mengatakan masih sedikit nyeri dengan skala 4 hilang timbul, sudah tidak pusing, tidak mual. Dari data objektif didapatkan suhu $36,2^{\circ} \mathrm{C}$, mukosa bibir lembab, makanan lunak dan minum 7 gelas sehari. Intervensi selanjutnya adalah monitor nyeri, monitor asupan makanan.

\section{KESIMPULAN}

Berdasarkan penelitian dapat disimpulkan bahwa asuhan keperawatan yang diberikan kepada 1 pasien hasilnya belum optimal. Pada pasien terjadi penurunan nyeri dari skala 6 turun skala 4 dengan kriteria nyeri sedang. Pasien mengatakan bisa melakukan teknik relaksasi sehingga sewaktu-waktu nyeri muncul pasien langsung mempraktikannya. Dalam pemeriksaan tanda-tanda vital didapatkan suhu $36,9^{\circ} \mathrm{C}$ setelah diberikan drip paracetamol 3x500gram menjadi turun yaitu $36,2^{\circ} \mathrm{C}$. Dalam penelitian ini hasil dari tujuan yang hendak dicapai pada pengelolaan asuhan keperawatan dengan masalah utama demam typhoid dengan monitor dan manajemen nyeri serta monitor asupan makanan.

\section{DAFTAR PUSTAKA}

Bulechec, G. M. dkk. (2013). Nursing Interventions Clasification. Edisi. 6, Jakarta: Elsevier 
Diri, K., Kebiasaan, D. A. N., \& Di, J. (2016).Analisis Risiko Kejadian Demam Typhoid Berdasarkan Kebersihan Diri Dan Kebiasaan Jajan Di Rumah. Jurnal Berkala Epidemiologi. 4, 74-86. 10.20473/jbe.v4i1.74-86.

Maarisit, C. L., Sarimin, S., \& Babakal, A. $(20,14)$. Hubungan Pengetahuan Orang Tua Tentang Demam Typhoid dengan Kebiasaan Jajan pada Anak di Wilayah Kerja Rsud Mala Kecamatan Melonguane Kabupaten Kepulauan Talaud. Jurnal Keperawatan, 2(2). Tersedia pada: https://ejournal.unsrat.ac.id/index.php/jkp/article/view/5666

Mahmudah., \& Kasman. (2014). Faktor yang Mempengaruhi Kejadian Penyakit Typhus Abdominalis di Ruang Rawat Inap Puskesmas Negara Kec. Daha Utara Kab. Hulu Sungai Selatan. An-Nadaa. 1(1), hal. 37-41.

Nanda, S. De., \& Maulina (tanpa tanggal). Perilaku Pencegahan Penyakit Demam Typhoid pada Mahasiswa, hal. 1-5.

Paputungan, W., Rombot, D., \& Akili, R.H. (2016). Hubungan Antara Perilaku Hidup Bersih Dan Sehat Dengan Kejadian Demam Typhoid di Wilayah Kerja Puskesmas Upai Kota Kotamobagu Tahun 2015,5(2), hal. 266-275.

Swanson., Elizabeth, et.al.(2013). Nursing Outcomes Clasifications (NOC) : Alih bahasa Intisari, N .(et al), Edisi V. Jakarta : CV Macomedia 